\title{
MELATONIN PROTECTS THE LIVER AND ERYTHROCYTES AGAINST OXIDATIVE STRESS IN CIRRHOTIC RATS
}

\author{
Darlan Pase da ROSA ${ }^{1,2}$, Silvia BONA ${ }^{1,2}$, Douglas SIMONETTO³, Claudio ZETTLER ${ }^{1}$, \\ Cláudio Augusto MARRONI ${ }^{3}$ and Norma Possa MARRONI ${ }^{1,2}$
}

\begin{abstract}
Context - Cirrhosis is a progressive chronic hepatopathy which constitutes an irreversible stage of liver dysfunction. Objectives - To evaluate the oxidative stress in the blood of cirrhotic rats treated with the antioxidant melatonin. Methods - Cirrhosis was induced through inhalation of carbon tetrachloride. Liver integrity was evaluated by measuring serum enzymes, oxidative damage measured by lipoperoxidation, and antioxidant enzyme activity in erythrocytes. Lipoperoxidation, total nitrates, collagen, and histology by picrosirius staining were evaluated in the livers of these animals $(n=15)$, which were divided in three groups: control, carbon tetrachloride, and carbon tetrachloride + melatonin. Melatonin $(20 \mathrm{mg} / \mathrm{kg})$ was administered intraperitoneal from week 10 of carbon tetrachloride inhalation. In order to shorten the cirrhosis induction time, phenobarbital $(0.3 \mathrm{~g} / \mathrm{L})$ was added to the animals' drinking water. Results - A significant impairment in the liver integrity of melatonin-treated animals as compared to cirrhotic animals was observed. In rat erythrocytes and liver, lipoperoxidation was significantly increased in the cirrhotic rats as compared to controls, as measured through thiobarbituric acid reactive substances, and significantly decreased in melatonin-treated animals as compared to cirrhotic ones. In blood, a decrease in superoxide dismutase and glutathione peroxidase enzymes was detected in the cirrhotic group as compared to the control group, with increased superoxide dismutase activity when melatonin was administered. A reduction in the levels of total nitrates was detected in the hepatic tissue of the animals in the carbon tetrachloride group as compared to the control group and an increase of these levels in the carbon tetrachloride + melatonin group. As for hepatic collagen, we found a significant increase in the carbon tetrachloride group as compared to the controls and a regression of these values in the treated group. In histology, the rats in the carbon tetrachloride group showed fibrosis and formation of fibrotic nodules, characterizing liver cirrhosis; there was reduction of nodules and fibrosis in the melatonin treated group. Conclusion - The data allow us to suggest that the observed oxidative stress is related to the damages caused by carbon tetrachloride and that the use of melatonin can minimize these damages. HEADINGS - Oxidative stress. Liver cirrhosis, experimental. Melatonin. Erythrocytes. Carbon tetrachloride. Rats.
\end{abstract}

\section{INTRODUCTION}

Cirrhosis is chronic disease whose natural history determines several complications with high morbidity and mortality. A worldwide health problem, cirrhosis is a progressive chronic disease with an early stage of slow, irreversible liver dysfunction, characterized by the formation of hepatic nodules resulting from fibrosis. Such structural alterations are the main responses of the hepatic tissue to the numerous aggressions of inflammatory, viral, toxic and congestive nature ${ }^{(44)}$.

The three main mechanisms involved in the generation of cirrhosis are: cell death, great deposition of the extracellular matrix in the liver (fibrosis), and cell reorganization. The accumulation of extracellular matrix observed in fibrosis and cirrhosis is due to the activation of fibroblasts, acquiring the form of myofibroblasts, which are absent in the normal liver.
They are produced by the activation of cell precursors, such as hepatic stellate cells ${ }^{(20,26)}$.

Cirrhosis is defined as the advanced stage of fibrosis, characterized by the formation of regenerative nodules in the hepatic parenchyma, with deposition of the extracellular matrix (predominantly collagen type I and III) in the space of Disse, this being directly responsible for the progressive reduction of the hepatic function $^{(14)}$.

Carbon tetrachloride $\left(\mathrm{CCl}_{4}\right)$ is a well-known hepatotoxin widely used to induce toxic hepatic lesion in experimental animals ${ }^{(6,25,37,38)}$. Hepatotoxicity is believed to result from two events: the first includes $\mathrm{CCl}_{4}$ metabolism by cytochrome P-450 to the trichloromethyl radical $\left(\mathrm{CCl}_{3}{ }^{\circ}\right)$, part of which generating the trichloromethylperoxyl radical $\left(\mathrm{OOCCl}_{3}\right)^{(37}$, ${ }^{40)}$, which leads to lipid peroxidation ${ }^{(11)}$; the second involves the activation of the Kupffer cells, which

'Lutheran University of Brazil, Canoas, RS; ${ }^{2}$ Clinical Hospital, Porto Alegre, RS; ${ }^{3}$ Federal University of Heath Sciences, Porto Alegre, RS, Brazil.

Correspondence: Dr. Cláudio Augusto Marroni - Rua José Kanam Aranha,102 - 90670-001 - Porto Alegre, RS, Brazil. E-mail: nmarroni@terra.com.br 
is accompanied by the production of pro-inflammatory mediators ${ }^{(32)}$.

In cirrhosis, alterations in the oxidant/antioxidant mechanisms have been described, which are in a state of unbalance and largely contribute to hepatic necrosis ${ }^{(9,38,46)}$. Recently, the oxidative stress has been suggested as one of the main causes of tissue lesion in several diseases ${ }^{(8,34)}$.

The production of reactive oxygen species (ROS) is considered as the main pathogenic mechanism of the alcoholic hepatic damage ${ }^{(21)}$. Several ROS are formed in the hepatocyte through the activation of Kupffer cells and inflammatory cells ${ }^{(29)}$.

Cirrhosis is associated with alterations in the systemic circulation. Erythrocytes are exposed to oxidative stress during their normal aerobic functions. In healthy people this stress is counterbalanced by a powerful enzymatic and non-enzymatic antioxidant system, something that does not happen with cirrhotic patients, in whose erythrocytes there is an increase in the oxidative stress ${ }^{(17,46)}$.

Antioxidant levels in plasma or erythrocytes are easily accessible, attractive parameters to obtain information on the repair of the oxidative hepatic damage ${ }^{(21,24,35,42)}$.

The use of antioxidants can help minimize the oxidative stress, contributing to the therapeutic intervention in cirrhotic livers ${ }^{(31,36,37,39,45,46)}$. Among the several antioxidants, melatonin (MEL) (N-acetyl-methoxytryptamin), an indolamine derived from triptophane, acts as a scavenger of oxygen free radicals ${ }^{(4)}$.

After its administration, MEL crosses the membranes freely and spreads through the compartments of all the body. MEL is 10 times more potent than vitamin $\mathrm{C}$ and a-tocopherol in breaking the chain reaction of lipid peroxidation. It seems to protect rats against experimentally-induced oxidative damage ${ }^{(12)}$. One molecule of MEL can bind to almost two peroxyl radicals, thus effectively protecting the DNA and the erythrocytes ${ }^{(49)}$. It is a potent "scavenger" of free radicals ${ }^{(15,16)}$ and it increases the activity of RNAm expression of different antioxidant enzymes ${ }^{(2,23,28)}$.

In view of these considerations, we used the model of liver cirrhosis induced by $\mathrm{CCl}_{4}$ inhalation in order to evaluate the liver through an assessment of serum enzymes, collagen, and histology and the erythrocytes, so as to relate the damages to the hepatic tissue to the expression of serum oxidative damages.

\section{METHODS}

\section{Animals}

The experimental procedures complied with the rules established by the "Research in Health and Animal Rights" according to the Commission of Research and Ethics in Health of the Research and Postgraduate Group of the Hospital de Clínicas de Porto Alegre, RS, Brazil ${ }^{(18)}$.

Fifteen male Wistar rats weighing $250 \mathrm{~g}$ were used. They were obtained from the Experimental Animals Facility of the Instituto de Ciências Básicas da Saúde da Universidade Federal do Rio Grande do Sul, Porto Alegre, RS. They were kept at the Animal Experimentation Unit of the Research Center of the Hospital de Clínicas of Porto Alegre in plastic boxes measuring $47 \times 34 \times 18 \mathrm{~cm}$ lined with wood chips, in a 12-hours dark/light cycle (light from 7 a.m. to 7 p.m.) at a temperature of $22 \pm 4^{\circ} \mathrm{C}$. The rats were fed $16 \mathrm{~g}$ per animal/ day on rat chow (Purina-Nutripal, Porto Alegre, RS, Brazil) and had water ad libitum.

\section{Groups and treatment protocols}

The animals were divided in three groups: I-Control; IICirrhotic; III-Cirrhotic+MEL. A Control+MEL group was not used because previous works showed that these did not differ significantly from the control rats.

MEL $\left(\right.$ Sigma $^{\circledR}$ ) was injected in a dose of $20 \mathrm{mg} / \mathrm{kg}$ of animal weight by way of intraperitoneal, diluted in $1 \mathrm{~mL}$ sodium solution $(\mathrm{NaCl} 0.9 \%)$ and ethanol $(8 \%)$. It was administered daily as from week 10 of $\mathrm{CCl}_{4}$ inhalation, when liver fibrosis and damage is fully established in these animals. $\mathrm{CCl}_{4}$ inhalation was extended for 16 weeks.

\section{Cirrhosis induction}

In order to reduce the cirrhosis development time, phenobarbital $(0.3 \mathrm{~g} / \mathrm{L})$ was added to the all rat's drinking water as an enzymatic inductor, to increase the metabolism of the $\mathrm{CCl}_{4}$ to its actives metabolites like trichloromethyl radical $\left(\mathrm{CCl}_{3}{ }^{\circ}\right)$. Administration started 1 week before the first $\mathrm{CCl}_{4}$ inhalation and was maintained until the end of the experiment. The cirrhotic group was exposed to $\mathrm{CCl}_{4}$ twice a week (Mondays and Fridays), in a inhalation chamber $(65 \times 26 \times 21 \mathrm{~cm}) . \mathrm{CCl}_{4}$ was put in a glass recipient (humidifier) attached to an air compressor with an flow rate of $1 \mathrm{~L} / \mathrm{min}$, according to Jimenez et al. ${ }^{(22)}$ and Cremonese et al. ${ }^{(9)}$.

In the first three sessions, the gas exposure length was 30 seconds, the rats remaining in the cage for additional 30 seconds with the compressor off. In the next three sessions, the gassing time was increased to 1 minute, followed by another minute with the compressor off. Then the gas exposure time and subsequent time of permanence in the chamber was increased by 30 seconds every three sessions, reaching the maximum time of 5 minutes within 16 weeks.

\section{Biochemical analysis}

At week 16 the animals were killed. First they were anaesthetized with ketamine $(100 \mathrm{mg} / \mathrm{kg})$ and xylasine $(50$ $\mathrm{mg} / \mathrm{kg}$ ) intraperitoneal. Through a heparinized capillary, blood was sampled from the retro-orbital plexus and divided into three parts for the performance of the liver integrity assays, measures of thiobarbituric acid reactive substances (TBARS), and antioxidant enzyme analyses. Subsequently trichotomy was performed followed by medium laparotomy, the liver being dissected out and divided in two parts: one for preparation of paraffin blocks and subsequent mounting onto histological slides, and the other frozen at $-80^{\circ} \mathrm{C}$ for posterior analyses.

\section{Liver homogenates}

The livers were cut with scissors and weighed. Nine $\mathrm{mL}$ of phosphate buffer (KCL $140 \mathrm{mM}$, phosphate $20 \mathrm{mM}$ and $\mathrm{pH}$ 7.4) per tissue gram was added and it was homogenized in Ultra Turrax (IKA-WERK) for 40 seconds at $4^{\circ} \mathrm{C}$. Next it 
was centrifuged for 10 minutes at 4,000 rpm (SORVALL RC5B Refrigerated Superspeed Centrifuged). The supernatant was pipetted into Eppendorf flasks and the precipitate was discarded. The samples were conditioned again at $-80^{\circ} \mathrm{C}$ for posterior analyses.

\section{Protein}

The method of bovine albumin solution (SIGMA) was used at a concentration of $1 \mathrm{mg} / \mathrm{mL}$, according to Lowry et al. ${ }^{(27)}$. The samples were measured spectrophotometrically at $625 \mathrm{~nm}$ and expressed as $\mathrm{mg} / \mathrm{mL}^{(27)}$, used for calculating TBARS in liver and antioxidant enzyme values.

\section{Liver peroxidation}

The quantity of aldehyde products generated by lipid peroxidation is quantified by the thiobarbituric acid reaction using $3 \mathrm{mg}$ of protein per sample. Results referring to TBARS. The samples were incubated at $90^{\circ} \mathrm{C}$ for $30 \mathrm{~min}$ and subsequently $500 \mu \mathrm{L}$ of thiobarbituric acid $(0.37 \%)$ was added to the trichloroacetic acid (15\%) and centrifuged at $4^{\circ} \mathrm{C}$ for $1613 \mathrm{x} \mathrm{g}$ for 15 minutes ${ }^{(5)}$.

\section{Erythrocyte peroxidation}

Blood was collected with heparin and centrifuged at $1613 \mathrm{x}$ g rpm for $5 \mathrm{~min}$ at $4^{\circ} \mathrm{C}$. The plasma was discarded and the erythrocytes were rinsed 3 times with the same volume of saline solution $(\mathrm{NaCl} 0.9 \%)$, the supernatant being discarded at each rinsing and the red cells reserved. Ten $\mu \mathrm{L}$ of rinsed red cells was pipetted for hemoglobin measurement according to the Drabkin technique ${ }^{(10)}$. Another $100 \mathrm{~mL}$ of rinsed red cells was pipetted to determine the products generated by lipid peroxidation through the TBARS technique. This was spectrophotometrically measured at $535 \mathrm{~nm}$ according to Yagi ${ }^{(48)}$.

\section{Antioxidant enzyme analyses}

To store the sample for the analyses of antioxidant enzymes, $150 \mu \mathrm{L}$ of the rinsed red cells were diluted in 1.5 $\mathrm{mL}$ of $1 \mathrm{mM}$ acetic acid and $4 \mathrm{mM} \mathrm{MgSO} 4$ and subsequently frozen at $-80^{\circ} \mathrm{C}$.

For the evaluation of antioxidant enzymes, these mixtures were unfrozen and centrifuged at $645 \mathrm{x}$ g for $30 \mathrm{sec}$, and the supernatant was used.

The analysis of superoxide dismutase (SOD) in erythrocytes is based on the inhibition of the reaction of the superoxide radical with adrenaline and was carried out according to Misra and Fridovich ${ }^{(30)}$. The analysis of the activity of enzyme catalase (CAT) is based on measuring the decrease in hydrogen peroxide, according to Aebi ${ }^{(1)}$. The activity of enzyme glutathione peroxidase (GPx) is based on the consumption of NADPH in the reaction of reduction of oxidized glutathione, according to Flohé and Guntzler ${ }^{(13)}$.

The measure of nitric oxide (NO) in the liver was performed by measuring nitrites and nitrates, consisting in the transformation of nitrates and nitrites through nitrate reductase and subsequently read at $550 \mathrm{~nm}^{(19)}$. Collagen concentration is determined by measuring the hydroxyproline contained in the acid digestion of the liver, which was spectrophotometrically read at $560 \mathrm{~nm}$ and the results expressed in $\mu \mathrm{g} / \mathrm{mg}$ of protein $^{(43)}$.

To evaluate the histological material, a part of the liver was left in $10 \%$ formaldehyde for $24 \mathrm{~h}$ and included in a paraffin block that was then cut into $6 \mu \mathrm{m}$ slices. The picrosirius technique highlights the presence of collagen in the sample.

The results are expressed as mean \pm standard error. The ANOVA was used for variance analysis and the StudentNewmann-Keuls for comparing groups, with a significance level of $5 \%(P<0.05)$. Spearman's $(r)$ correlation was used to compare non-parametric variables.

\section{RESULTS}

\section{Biochemical analysys}

Transferase enzymes (AST and ALT) - markers of hepatic damage - were significantly increased in the cirrhotic group $(P<0.05)$ as compared to the $\mathrm{CCl}_{4}+\mathrm{MEL}$ group $(P<0.05)$ (Table 1).

TABLE 1. AST and ALT values

\begin{tabular}{lccc}
\hline & $\mathrm{CO}$ & $\mathrm{CCl}_{4}$ & $\mathrm{CCl}_{4}+\mathrm{MEL}$ \\
\hline $\mathrm{AST}_{(\mathrm{U} / \mathrm{L})}$ & $132.4 \pm 15.44$ & $530.4 \pm 64.1^{\mathrm{a}}$ & $381.8 \pm 66.6^{\mathrm{b}}$ \\
$\mathrm{ALT}_{(\mathrm{U} / \mathrm{L})}$ & $37.4 \pm 2.8$ & $304.2 \pm 33.7^{\mathrm{a}}$ & $173.0 \pm 27.4^{\mathrm{c}}$ \\
\hline
\end{tabular}

2: $P<0.001$ vs $\mathrm{CO}$; b: $P<0.01$ vs $\mathrm{CCl}_{i} ;$ c: $P<0.001$ vs $\mathrm{CCl}$

$\mathrm{CO}$ : control group; $\mathrm{CCl}$ cirrhotic group; $\mathrm{CCl}+\mathrm{MEL}$ : cirrhotic group treated with melatonin

AST: aspartate aminotransferase; ALT: alanine aminotransferase

\section{Lipoperoxidation}

The results obtained through the TBARS method in the liver and blood showed that there was increased lipoperoxidation in the cirrhotic group as compared to the controls $(>180 \%)$. In the MEL-treated group these values were close to the ones of the control group in both the hepatic tissue and erythrocytes (Figure 1 and 2). There was a close association between liver TBARS and erythrocyte TBARS (Figure 3; $r=0.690$ ).

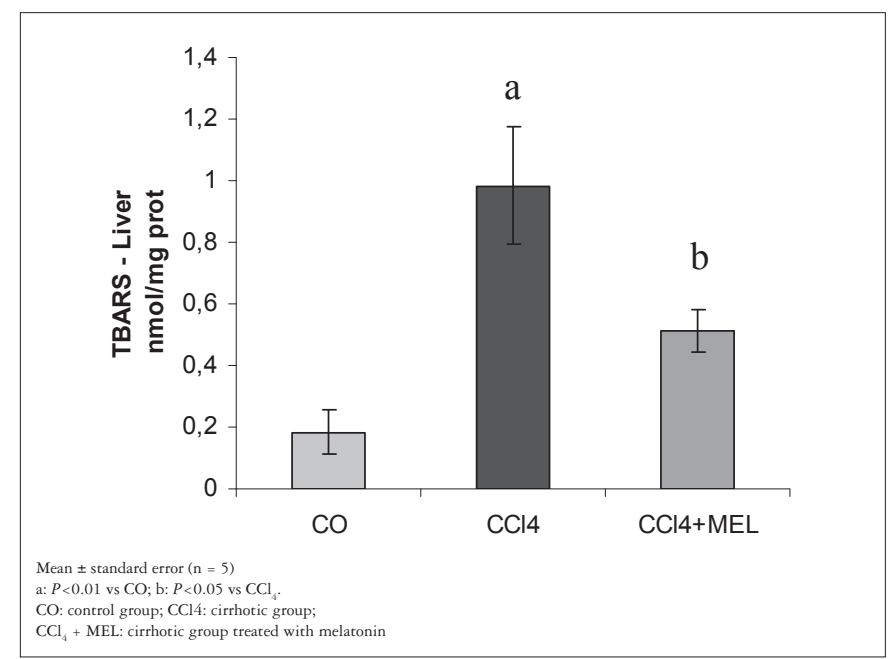

FIGURE 1. Effect of $\mathrm{CCl}_{4}$ inhalation and melatonin administration on liver lipoperoxidation analyzed by the TBARS method 


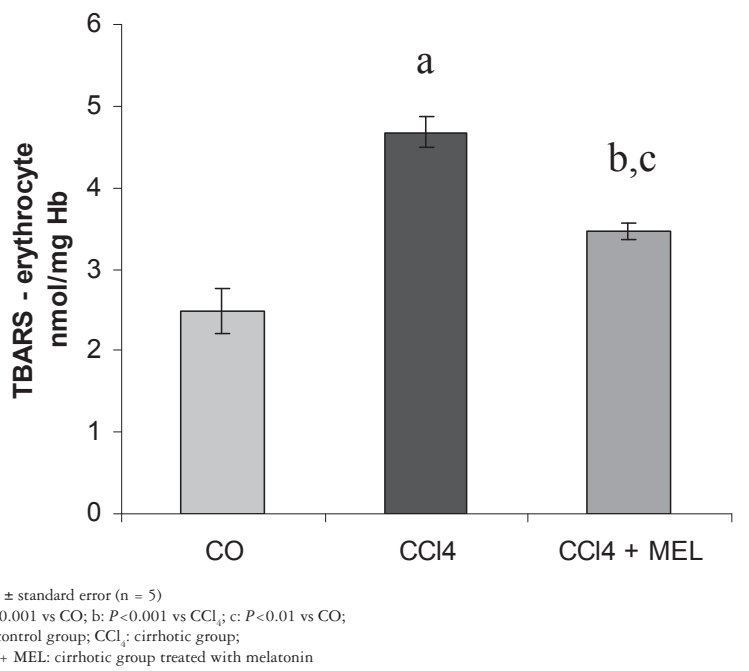

FIGURE 2. Effect of $\mathrm{CCl}_{4}$ inhalation and melatonin administration on erythrocyte lipoperoxidation analyzed by the TBARS method

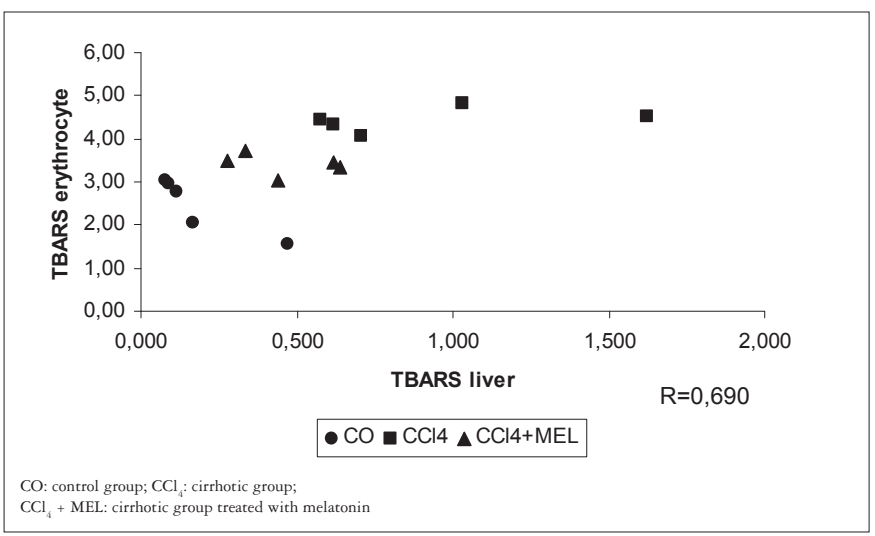

FIGURE 3. Relationship between TBARS liver and TBARS erythrocyte; the correlation was highly significant $(r=0,690, P<0,004)$

\section{Antioxidant enzymes}

The activities of antioxidant enzymes SOD and GPx in the erythrocytes of the cirrhotic group were diminished as compared to the cirrhotic group. While GPx activity was about the same in the $\mathrm{CCl}_{4}$ and in the $\mathrm{CCl}_{4}+\mathrm{MEL}$ groups, SOD activity was increased in the rats that received MEL as compared to untreated cirrhotic rats. Catalase (CAT) activity did not differ significantly across the groups (Table 2).

TABLE 2. Evaluation of SOD, GPx and CAT activities

\begin{tabular}{lccc}
\hline & $\mathrm{CO}$ & $\mathrm{CCl}_{4}$ & $\mathrm{CCl}_{4}+\mathrm{MEL}$ \\
\hline $\mathrm{SOD}_{\text {(USOD/mg prot) }}$ & $31.15 \pm 2.88$ & $12.65 \pm 2.33^{\mathrm{a}}$ & $22.11 \pm 1.58^{\mathrm{b}, \mathrm{c}}$ \\
$\mathrm{GPx}_{\text {(mmoles/min/mg prot) }}$ & $1.46 \pm 0.34$ & $0.72 \pm 0.03^{\mathrm{b}}$ & $0.67 \pm 0.03^{\mathrm{b}}$ \\
$\mathrm{CAT}_{\text {(pmoles/mg de prot) }}$ & $0.011 \pm 0.002$ & $0.008 \pm 0.001$ & $0.007 \pm 0.001$ \\
\hline
\end{tabular}

a: $P<0.01$ vs $\mathrm{CCl}_{4} ;$ b: $P<0,05$ vs $\mathrm{CO} ; \mathrm{c:}: P<0,05$ vs $\mathrm{CCl}$;

mean \pm standard error $(\mathrm{n}=5)$; $\mathrm{CO}$ : control group; $\mathrm{CCl}$ : cirrhotic group;

$\mathrm{CCl}_{4}+\mathrm{MEL}$ : cirrhotic group treated with melatonin
NO

Concerning the level of $\mathrm{NO}$ in the liver, we detected a significant decrease in the NO metabolites in cirrhotic rats as compared to controls, and MEL was not able to reverse this situation (Table 3 ).

TABLE 3. Evaluation of NO in the hepatic tissue through the measure of total nitrites and nitrates metabolites

\begin{tabular}{lccc}
\hline & $\mathrm{CO}$ & $\mathrm{CCl}_{4}$ & $\mathrm{CCl}_{4}+\mathrm{MEL}$ \\
\hline Nitrites $_{(\text {Umol/L) }}$ & $6.14 \pm 0.94$ & $2.60 \pm 0.23^{\mathrm{a}}$ & $3.29 \pm 0.52^{\mathrm{a}}$ \\
Total nitrates $_{(\mathrm{Umol} / \mathrm{L})}$ & $0.274 \pm 0.012$ & $0.130 \pm 0.010^{\mathrm{b}}$ & $0.100 \pm 0.009^{\mathrm{b}}$ \\
\hline
\end{tabular}

a $P<0.01$ vs $\mathrm{CO}$; b: $P<0.001$ vs $\mathrm{CO}$; mean \pm standard error $(\mathrm{n}=5)$; $\mathrm{CO}$ : control group;

$\mathrm{CCl}$ : cirrhotic group; $\mathrm{CCl}+\mathrm{MEL}$ : cirrhotic group treated with melatonin

\section{Collagen}

A significant increase in the concentration of collagen was observed in the cirrhotic animals as compared to the control group, while in the MEL-treated group these values were decreased as compared to those of untreated cirrhotic animals (Figure 4). There was a close association between TBARS and collagen concentration in the liver (Figure 5; $r=0.904$ ).

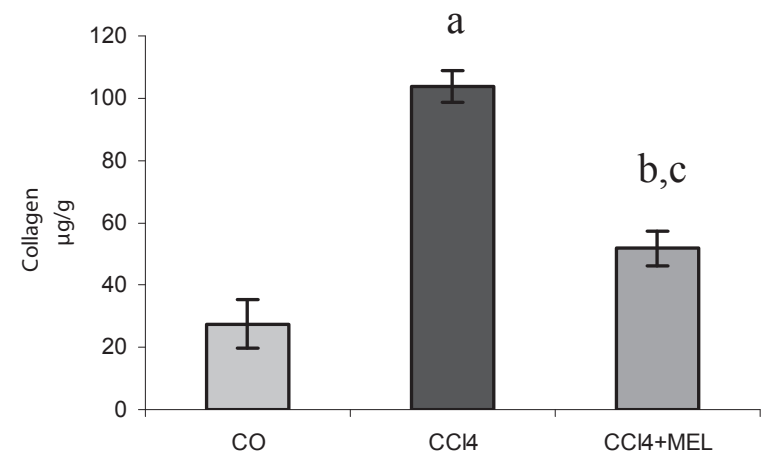

mean \pm standard error $(\mathrm{n}=5)$

a: $P<0.001$ vs $\mathrm{CO}$; b: $P<0.001$ vs $\mathrm{CCl}_{4}$; $: P<0.05$ vs $\mathrm{CO}$;

$\mathrm{CO}$ : control group; $\mathrm{CCl}_{4}$ : cirrhotic group; $\mathrm{CCl}_{4}+\mathrm{MEL}$; cirrhotic group treated with melatoni

FIGURE 4. Effect of $\mathrm{CCl}_{4}$ inhalation and melatonin administration on collagen concentration in the liver

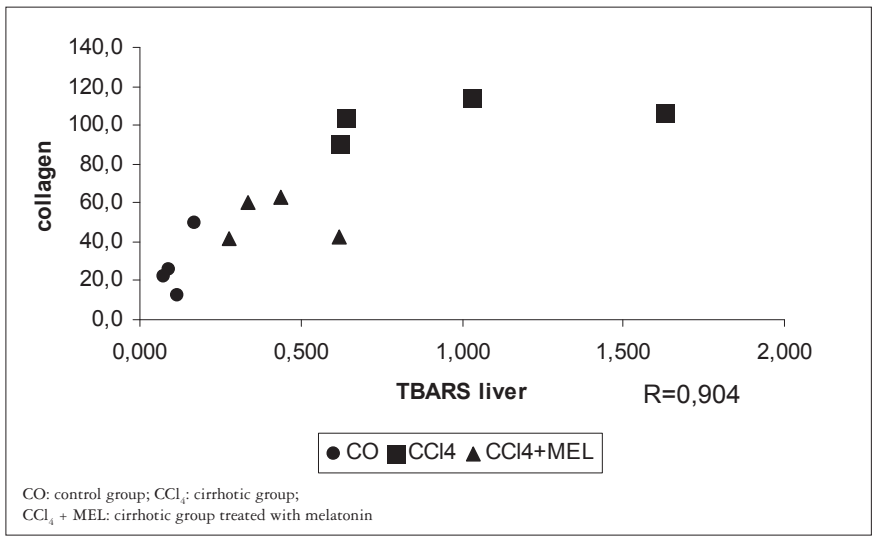

FIGURE 5. Relationship between TBARS liver and collagen concentration in the liver; the correlation was highly significant $(r=0,904, P<0,001)$ 


\section{Histology}

The histology of $\mathrm{CCl}_{4}$ animals in week 10 showed the presence of nodular fibrosis (Figure 6B) in contrast with controls (Figure 6A). In week 16, the $\mathrm{CCl}_{4}$ rats presented severe cirrhosis with a high concentration of nodular fibrosis and collagen (Figure 6C), while MEL-treated animals showed a regression of this picture with moderate fibrosis (Figure 6D).
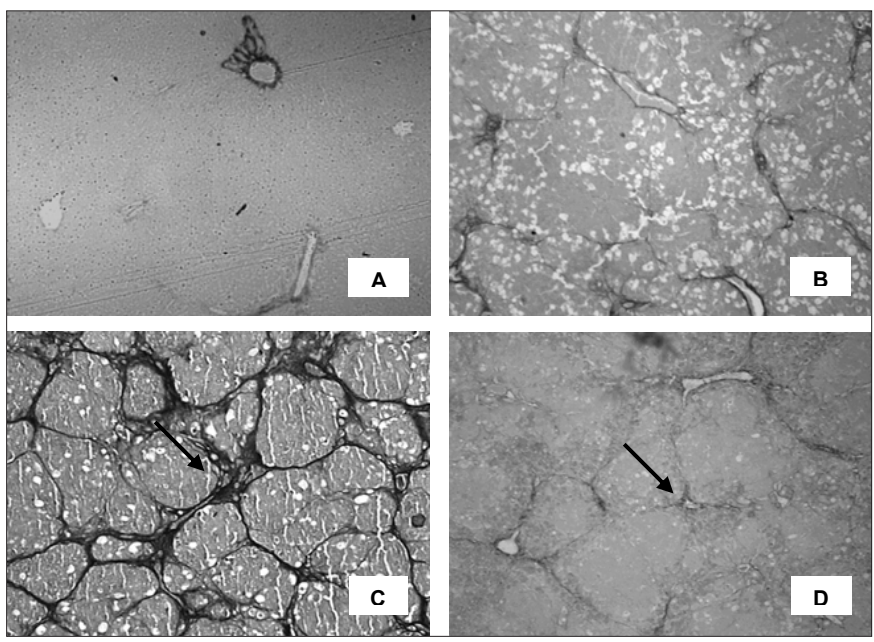

FIGURE 6. A. liver of control rat; B. liver of cirrhotic rat in week 10 of $\mathrm{CCl}_{4}$ inhalation; $\mathrm{C}$. liver of cirrhotic rat in week 16 of $\mathrm{CCl}_{4}$ inhalation; D. liver of MEL-treated cirrhotic rat. Picrosirius stain (40x)

\section{DISCUSSION}

It has been recognized that the trichloromethyl $\left(\mathrm{CCl}_{3}{ }^{\circ}\right)$ and the trichloromethylperoxyl $\left(\mathrm{OOCCl}_{3}{ }^{\circ}\right)$ free radicals, formed after $\mathrm{CCl}_{4}$ is metabolized by cytochrome $\mathrm{p}-450$, affect pathologically all parts of the hepatocyte ${ }^{(3)}$ and cause morphological alterations involving the endoplasmic reticulum, the Golgi complex, the plasma membrane and the mitochondria of these cells ${ }^{(7)}$. These alterations damage and eventually kill these cells, leading to tissue fibrosis which, organized in nodules, will characterize hepatic cirrhosis ${ }^{(41)}$.

The induction of liver cirrhosis through $\mathrm{CCl}_{4}$ inhalation is an effective experimental model to evaluate the oxidative injury resulting from the formation of free radicals ${ }^{(9,38)}$. The liver integrity assays performed here showed tissue damage in the animals of the cirrhotic group, with at least a 400 -fold increase, as well as decreased levels of injury in the animals of the group treated with antioxidant MEL, as previously reported for the administration of other antioxidants such as $\mathrm{N}$-acetylcysteine ${ }^{(38)}$ and quercetin ${ }^{(37,46)}$, evidencing protection against liver injury in these animals.

Lipoperoxidation is a marker of cell membrane damage, and the measure of malondialdehyde, which is a product of this damage, is performed through the TBARS technique. Here we have assessed lipoperoxidation in the liver and also in the erythrocytes. We found a significant increase of this marker in both samples of the cirrhotic group as compared to the controls and a decrease in the animals receiving MEL as compared to $\mathrm{CCl}_{4}$-intoxicated animals. These data show that there is oxidative damage to the membrane of these cells, and that MEL decreases such damage ${ }^{(17,37,38,46,47)}$. Furthermore, our data show a strong correlation between liver TBARS and erythrocyte TBARS $(\mathrm{r}=0.690)$.

Endogenous antioxidant enzymes are the primary responsible for the defense of the organism against these oxidative agents. The main ones are CAT, SOD, and GPx. In the present work, there was no significant difference in CAT activity in erythrocytes between the groups, which can be explained by the decreased SOD and consequently decreased GPx in the cirrhotic group, CAT activity being unaltered, given that the free radical is primarily reduced by SOD which then forms $\mathrm{H}_{2} \mathrm{O}_{2}$ which, in turn, will be reduced by GPx or CAT. The evaluation of GPx activity showed it was significantly reduced in cirrhotic animals as compared to controls. SOD activity in cirrhotic rats was decreased by $40 \%$ as compared to controls, and improved to $57 \%$ in MEL-treated animals. This can be the result of an indirect action of MEL, which stimulates SOD synthesis.

The reductions of endogenous antioxidant enzymes in cirrhotic animals, together with the results of lipoperoxidation, establish a picture of oxidative stress in these animals ${ }^{(33)}$. MEL treatment reduced lipoperoxidation and increased SOD activity, showing a significant improvement of the oxidative stress in these animals.

$\mathrm{NO}$ is an important vasodilator in the vascular system. In the evaluation of NO performed here by measuring total nitrate and nitrite metabolites, cirrhotic rats presented a significant reduction as compared to the controls, showing an unbalance in the intra-hepatic vasodilator/vasoconstrictor system $^{(46)}$. Nevertheless, MEL at the dose used here was not able to restore these levels.

Collagen is synthesized through the activation of hepatic stellate cells in a physiological measure of tissue regeneration. The quantification of collagen in the livers of cirrhotic animals showed that it was 381 times higher than in controls, and 198 times lower in MEL-treated than in cirrhotic rats, just like Pereira-Filho et al. ${ }^{(38)}$ reported for the treatment with another antioxidant. Furthermore, our data show a strong correlation between TBARS and collagen concentration in the liver $(r=0.904)$.

The histological analysis using picrosirius staining showed the presence of collagen and the formation of fibrotic microand macro-nodules, characterizing liver fibrosis, and a decrease of these damages in the livers of MEL-treated animals, as previously observed in works using NAC and quercetin in cirrhotic animals ${ }^{(37,38,45,46)}$.

The data lead us to suggest that MEL decreases the oxidative stress by acting as scavenger of free radicals and providing antioxidant protection of biomolecules. MEL significantly reduces the lipoperoxidation levels in liver and erythrocytes, significantly decreases collagen in the liver, and increases the antioxidant enzyme SOD activity in erythrocytes.

MEL is a potent free radicals scavenger with a broad spectrum of antioxidant capability. It could induce the activity of antioxidant enzymes and alleviate the liver imbalance of antioxidant/proxidant level. Therefore it can act protecting 
the cirrhotic liver by decreasing the oxidative damage and ameliorating the organ and its injury.

The results obtained here are similar to those reported by our group for other evaluations of liver tissue, using other models of cirrhosis and evaluating other antioxidants, such as $\mathrm{N}$-acetylcysteine and quercetin ${ }^{(37,38,46)}$, showing efficacy of the dosing used in rat erythrocytes for evaluation of systemic oxidative stress.

\section{CONCLUSION}

MEL administration reduced liver damage and lipoperoxidation and increased the antioxidant enzyme SOD, thus showing liver protection against this aggressor.

The measure of oxidative stress in peripheral blood seems to be effective for the analysis of liver fibrosis, reproducing the oxidative damage seen in the liver tissue.

Rosa DP, Bona S, Simonetto D, Zattler C, Marroni CA, Marroni NP. Melatonina protege o fígado e eritrócitos do estresse oxidativo em ratos cirróticos. Arq Gastroenterol. 2010;47(1):72-8.

RESUMO - Contexto - A cirrose é uma hepatopatia crônica e progressiva que constitui estágio irreversível de disfunção hepática. É associada a alterações na circulação sistêmica. Objetivos - Avaliar o estresse oxidativo no sangue de ratos cirróticos e tratados com antioxidante melatonina. Métodos - A cirrose foi induzida através da inalação de tetracloreto de carbono. Foram avaliadas as provas de integridade hepática através das medidas das enzimas séricas, o dano oxidativo medido pela lipoperoxidação e a atividade das enzimas antioxidantes no eritrócito. No fígado desses animais, foram avaliados a lipoperoxidação, os nitratos totais, colágeno e histologia através de picrosíruis. Os animais $(\mathrm{n}=15)$ foram divididos em três grupos experimentais: controle, tetracloreto de carbono e tetracloreto de carbono + melatonina. A melatonina foi administrada por via intraperitonial após a $10^{\mathrm{a}}$ semana de inalação na concentração de $20 \mathrm{mg} / \mathrm{kg}$. Com o objetivo de abreviar o tempo de indução, foi administrado para todos animais, fenobarbital na água de beber na concentração de $0,3 \mathrm{~g} / \mathrm{L}$. Resultados - Observou-se redução significativa nas provas de integridade hepática nos animais tratados com melatonina, em relação aos animais cirróticos. Nos eritrócitos e fígados dos ratos, foi observado aumento significativo da lipoperoxidação nos ratos cirróticos em comparação com os controles, através da medida das substâncias que reagem ao ácido tiobarbitúrico, e redução nos animais tratados com melatonina. No sangue, observou-se diminuição dos valores das enzimas superóxido dismutase e glutationa peroxidase do grupo cirrótico em comparação ao grupo controle, elevando a atividade da superóxido dismutase quando administrada melatonina. Na avaliação dos nitratos totais, no tecido hepático, observou-se redução dos valores nos animais do grupo tetracloreto de carbono em comparação ao grupo CO e um aumento desses valores nos ratos do grupo tratado com melatonina. Na medida do colágeno hepático, encontrou-se aumento significativo do grupo tetracloreto de carbono em relação ao controle e regressão desses valores no grupo tratado. Através da histologia, os ratos do grupo tetracloreto de carbono apresentaram presença de fibrose e formação de nódulos fibróticos, caracterizando a cirrose hepática; após o tratamento com a melatonina, houve redução dos nódulos e da fibrose. Conclusão - Com esses dados, pode-se sugerir que a análise do estresse oxidativo no sangue está relacionado ao dano hepático causado pelo tetracloreto de carbono e que o uso de melatonina pode minimizar esses danos.

DESCRITORES: Estresse oxidativo. Cirrose hepática experimental. Melatonina. Eritrócitos. Tetracloreto de carbono. Ratos.

\section{REFERENCES}

1. Aebi H. Catalase in vitro. Methods Enzymol. 1984;105:121-6,

2. Antolin I, Rodriguez C, Sainz RM, Mayo JC, Uria H, Kotler ML, RodriguezColunga MJ, Tolivia D, Menendez-Pelaez A. Neurohormone melatonin prevents cell damage: effect on gene expression for antioxidant enzymes. Faseb J. 1996;10: 882-90.

3. Boveris A, Fraga CG, Varsavsky AI, Koch OR. Increased chemiluminescence and superoxide production in the liver of chronically ethanol-treated rats. Arch Biochem Biophys. 1983;227:534-41.

4. Brzezinski A. Melatonin in humans. N Engl J Med. 1997;336:186-95.

5. Buege JA, Aust SD. Microsomal lipid peroxidation. Methods Enzymol. 1978;52:302-10.

6. Butler TC. Reduction of carbon tetrachloride in vivo and reduction of carbon tetrachloride and chloroform in vitro by tissues and tissue constituents. J Pharmacol Exp Ther. 1961;134:311-9.

7. Cameron TW. Parasites of animals and the public health in North America. Am J Public Health Nations Health. 1936;26:46-50.

8. Cesaratto L, Vascotto C, Calligaris S, Tell G. The importance of redox state in liver damage. Ann Hepatol. 2004;3:86-92.

9. Cremonese RV, Pereira-Filho AA, Magalhaes R, de Mattos AA, Marroni CA, Zettler CG, Marroni NP. Experimental cirrhosis induced by carbon tetrachloride inhalation: adaptation of the technique and evaluation of lipid peroxidation. Arq Gastroenterol. 2001;38:40-7.
10. Drabkin DL. Spectrophotometric studies. I. Spectrophotometric constants for common hemoglobin derivatives in human, dog, and rabbit blood. J Biol Chem. 1932;98:719-33.

11. Edwards MJ, Keller BJ, Kauffman FC, Thurman RG. The involvement of Kupffer cells in carbon tetrachloride toxicity. Toxicol Appl Pharmacol. 1993;119:275-9.

12. El-Missiry MA, Fayed TA, El-Sawy MR, El-Sayed AA. Ameliorative effect of melatonin against gamma-irradiation-induced oxidative stress and tissue injury. Ecotoxicol Environ Saf. 2007;66:278-86.

13. Flohe L, Gunzler WA. Assays of glutathione peroxidase. Methods Enzymol 1984;105:114-21.

14. Friedman SL. Liver fibrosis -- from bench to bedside. J Hepatol. 2003;38(Suppl 1): $\mathrm{s} 38-\mathrm{s} 53$.

15. Garcia JJ, Reiter RJ, Guerrero JM, Escames G, Yu BP, Oh CS, Munoz-Hoyos A. Melatonin prevents changes in microsomal membrane fluidity during induced lipid peroxidation. FEBS Lett. 1997;408:297-300.

16. Garcia JJ, Reiter RJ, Ortiz GG, Oh CS, Tang L, Yu BP, Escames G. Melatonin enhances tamoxifen's ability to prevent the reduction in microsomal membrane fluidity induced by lipid peroxidation. J Membr Biol. 1998;162:59-65.

17. Geetha A, Lakshmi Priya MD, Jeyachristy SA, Surendran R. Level of oxidative stress in the red blood cells of patients with liver cirrhosis. Indian J Med Res. 2007;126:204-10

18. Goldin JR, Raymundo MM. Pesquisa em saúde e direitos dos animais. $2^{\mathrm{a}}$ ed. Porto Alegre: HCPA; 1997

19. Granger DL, Anstey NM, Miller WC, Weinberg JB. Measuring nitric oxide production in human clinical studies. Methods Enzymol. 1999;301:49-61 
20. Guyot C, Lepreux S, Combe C, Doudnikoff E, Bioulac-Sage P, Balabaud C, Desmouliere A. Hepatic fibrosis and cirrhosis: the (myo) fibroblastic cell subpopulations involved. Int J Biochem Cell Biol. 2006;38:135-51.

21. Hagymasi K, Blazovics A, Lengyel G, Kocsis I, Feher J. Oxidative damage in alcoholic liver disease. Eur J Gastroenterol Hepatol. 2001;13:49-53.

22. Jimenez W, Claria J, Arroyo V, Rodes J. Carbon tetrachloride induced cirrhosis in rats: a useful tool for investigating the pathogenesis of ascites in chronic liver disease. J Gastroenterol Hepatol. 1992;7:90-7.

23. Kotler M, Rodriguez C, Sainz RM, Antolin I, Menendez-Pelaez A. Melatonin increases gene expression for antioxidant enzymes in rat brain cortex. J Pineal Res. 1998;24:83-9.

24. Lecomte E, Herbeth B, Pirollet P, Chancerelle Y, Arnaud J, Musse N, Paille F, Siest G, Artur Y. Effect of alcohol consumption on blood antioxidant nutrients and oxidative stress indicators. Am J Clin Nutr. 1994;60:255-61.

25. Lee CH, Park SW, Kim YS, Kang SS, Kim JA, Lee SH, Lee SM. Protective mechanism of glycyrrhizin on acute liver injury induced by carbon tetrachloride in mice. Biol Pharm Bull. 2007;30:1898-904

26. Lotersztajn S, Julien B, Teixeira-Clerc F, Grenard P, Mallat A. Hepatic fibrosis: molecular mechanisms and drug targets. Annu Rev Pharmacol Toxicol. 2005;45: 605-28.

27. Lowry OH, Rosebrough NJ, Farr AL, Randall RJ. Protein measurement with the folin phenol reagent. J Biol Chem. 1951;193:265-75.

28. Mauriz JL, Molpeceres V, Garcia-Mediavilla MV, Gonzalez P, Barrio JP, GonzalezGallego J. Melatonin prevents oxidative stress and changes in antioxidant enzyme expression and activity in the liver of aging rats. J Pineal Res. 2007;42:222-30.

29. McClain CJ, Barve S, Deaciuc I, Kugelmas M, Hill D. Cytokines in alcoholic liver disease. Semin Liver Dis. 1999;19:205-19.

30. Misra HP, Fridovich I. The role of superoxide anion in the autoxidation of epinephrine and a simple assay for superoxide dismutase. J Biol Chem. 1972;247:3170-5.

31. Muriel P, Suarez OR, Gonzalez P, Zuniga L. Protective effect of S-adenosyl-1methionine on liver damage induced by biliary obstruction in rats: a histological, ultrastructural and biochemical approach. J Hepatol. 1994;21:95-102.

32. Nakahira K, Takahashi T, Shimizu H, Maeshima K, Uehara K, Fujii H, Nakatsuka H, Yokoyama M, Akagi R, Morita K. Protective role of heme oxygenase-1 induction in carbon tetrachloride-induced hepatotoxicity. Biochem Pharmacol. 2003;66:1091-105.

33. Osman HG, Gabr OM, Lotfy S, Gabr S. Serum levels of bcl-2 and cellular oxidative stress in patients with viral hepatitis. Indian J Med Microbiol. 2007;25:323-9.

34. Padhy BM, Srivastava A, Kumar VL. Calotropis procera latex affords protection against carbon tetrachloride induced hepatotoxicity in rats. J Ethnopharmacol. 2007;113:498-502.
35. Parola M, Leonarduzzi G, Robino G, Albano E, Poli G, Dianzani MU. On the role of lipid peroxidation in the pathogenesis of liver damage induced by longstanding cholestasis. Free Radic Biol Med. 1996;20:351-9.

36. Pavanato A, Tuñon MJ, Sanchez-Campos S, Marroni CA, Llesuy S, GonzalezGallego J, Marroni N. Effects of quercetin on liver damage in rats with carbon tetrachloride-induced cirrhosis. Dig Dis Sci. 2003;48:824-9.

37. Pavanato A, Marroni N, Marroni CA, Llesuy F. Quercetin prevents oxidative stress in cirrhotic rats. Dig Dis Sci. 2007;52:2616-21.

38. Pereira-Filho G, Ferreira C, Schwengber A, Marroni C, Zettler C, Marroni N. Role of $\mathrm{N}$-acetylcysteine on fibrosis and oxidative stress in cirrhotic rats. Arc Gastroenterol. 2008;45:156-62.

39. Peres W, Tunon MJ, Collado PS, Herrmann S, Marroni N, Gonzalez-Gallego J. The flavonoid quercetin ameliorates liver damage in rats with biliary obstruction. J Hepatol. 2000;33:742-50.

40. Poyer JL, McCay PB, Lai EK, Janzen EG, Davis ER. Confirmation of assignment of the trichloromethyl radical spin adduct detected by spin trapping during $13 \mathrm{C}$-carbon tetrachloride metabolism in vitro and in vivo. Biochem Biophys Res Commun. 1980;94:1154-60.

41. Recknagel RO, Glende EA, Jr., Dolak JA, Waller RL. Mechanisms of carbon tetrachloride toxicity. Pharmacol Ther. 1989;43:139-54.

42. Rocchi E, Borghi A, Paolillo F, Pradelli M, Casalgrandi G. Carotenoids and liposoluble vitamins in liver cirrhosis. J Lab Clin Med. 1991;118:176-85.

43. Rojkind M, Gonzalez E. An improved method for determining specific radioactivities of proline-14C and hydroxyproline-14C in collagen and in noncollagenous proteins. Anal Biochem. 1974;57:1-7.

44. Tieppo J, Vercelino R, Dias AS, Marroni CA, Marroni N. Common bile duct ligation as a model of hepatopulmonary syndrome and oxidative stress. Arq Gastroenterol. 2005;42:244-8.

45. Tieppo J, Vercelino R, Dias AS, Silva Vaz MF, Silveira TR, Marroni CA, Marroni NP, Henriques JA, Picada JN. Evaluation of the protective effects of quercetin in the hepatopulmonary syndrome. Food Chem Toxicol. 2007;45:1140-6.

46. Viera EK. O efeito da quercetina no estresse oxidativo sistêmico em ratos cirróticos. Canoas: Universidade Luterana do Brasil; 2008.

47. Wu Y, Li L, Wen T, Li YQ. Protective effects of echinacoside on carbon tetrachloride-induced hepatotoxicity in rats. Toxicology. 2007;232:50-6.

48. Yagi K. Assay for blood plasma or serum. Methods Enzymol. 1984;105:328-31.

49. Zhao F, Liu ZQ, Wu D. Antioxidative effect of melatonin on DNA and erythrocytes against free-radical-induced oxidation. Chem Phys Lipids. 2008;151:77-84.

Received 19/11/2008 Accepted 23/3/2009. 